\title{
Reviewer Acknowledgements for Global Journal of Health Science, Vol. 12, No. 12
}

Global Journal of Health Science wishes to acknowledge the following individuals for their assistance with peer review of manuscripts for this issue. Their help and contributions in maintaining the quality of the journal are greatly appreciated.

Global Journal of Health Science is recruiting reviewers for the journal. If you are interested in becoming a reviewer, we welcome you to join us. Please contact us for the application form at: gjhs@ccsenet.org.

\section{Reviewers for Volume 12, Number 12}

Abin Varghese, Ministry of Health and Family Welfare, India

Ayesha Johnson, University of South Florida, United States of America

Carlos Aceves-Gonzalez, Ergonomic Research Centre of University of Guadalajara, Mexico

David John Lindsay, James Cook University, Australia

David Richard Walwyn, University of Pretoria, South Africa

Farahnaz Amini, UCSI University, Malaysia

Fengsong Gao, The University of Queensland, Australia

Francisco Rodenas Rigla, University of Valencia, Spain

Gavric Zivana, University Banja Luka, Bosnia and Herzegovina

Helen Lida Smits, Institute of Healthcare Improvement in Boston, United States of America

Hilal Hamood Alrahbi, Diwan of Royal Court-Oman, Oman

Jason Tsai, Lincoln College, United Kingdom

Jeffery T Spickett, School of Public Health Curtin University Perth Western Australia, Australia

José Joaquín Mira, Universidad Miguel Hernández, Spain

Le Thi Thanh Xuan, Hanoi Medical University, Viet Nam

Loray Daws, British Columbia Masterson Institute, Canada

Manuela Mauceri, University of Catania, Italy

Maria Malliarou, University of Thessaly, Greece

Pi-Ming Yeh, Missouri Western State University, United States

Piotr Raźniak, Pedagogical University of Cracow, Poland

Regina E. Ella, University of Calabar, Nigeria

Santhamma James, Australian Catholic University, Australia

Thanusin Saleeon, Ministry of Public Health, Thailand

Valery Piacherski, Mogilev Regional Hospital, Belarus 